\title{
Conversational activity in natural interaction for children
}

\section{Keyman Fuat}

Research Institute of Language Studies

Corresponding email: keymanfuat@rils.org

I propose to explain the reasons assuming that the precondition for understanding beliefs is children's participation in exchanges of information in conversation. I report that children are able to discuss past events more than three months old, giving selective information in depending on the presence or absence of the interlocutor as a spectator of these events; they seek information by asking questions with diverse formulations; they can respond appropriately to an information exchange in a dead end clarifying their words; finally, they use "no" not only to refuse but also to express disagreement in response to a question or opinion. So, children spontaneously use conversation as a means of research and exchange information, regardless of an action plan.

Studies have identified the first conversations between peers at the end of the first year: focus on the same theme and alternation of voice broadcasts. Alternating speaking turns between peers is mastered from the age of three, but it remains accompanied by an important gesture which it is necessary to transcribe in the corpora to understand them. The speaking turns become longer and more complex. Finally, the development of coverbal gestures in conversation neither does it show any particularity at a given age. 
Therefore, within situations spontaneous interactions, children are very early partners in conversation with peers or adults.

Children will have to go a long way before avoiding the conversational pitfalls posed by adults in artificial situations where they are asked about isolated tasks or meaningless. Questioning methods often underestimate children's competence interviewed. They seem to prefer the logical interpretations of connectors and modals rather than their pragmatic interpretations.

In some contexts where it is clear to them asked to assess the appropriateness of the sayings rather than their veracity, they become able to appreciate pragmatic interpretations or even make inferences appropriate pragmatics following violations of conversational maxims. Placing many tasks go against certain general pragmatic principles which confuse the children and introduce a distraction leading them to believe that the presence of objects in the experimental setting implies that they are used to interpret the adult request otherwise these objects would not be there. If the adult asks the same question after handling objects, the new answer expected is interpreted as being related to this manipulation; and the child modify his answer.

\section{REFERENCES}

Atance, C. M., \& Jackson, L. K. (2009). The development and coherence of futureoriented behaviors during the preschool years. Journal of Experimental Child Psychology, 102(4), 379-391. 
Atance, C. M., \& Meltzoff, A. (2005). My future self: Young children's ability to anticipate and explain future states. Cognitive Development, 20(3), 341-361.

Atance, C. M., \& O'Neill, D. K. (2001). Episodic future thinking. Trends in Cognitive Sciences, 5(12), 533-539.

Dickinson, D. K., Darrow, C. L., \& Tinubu, T. A. (2008). Patterns of teacher-child conversations in head start classroom: Implications for an empirically grounded approach to professional development. Early Education and Development, 19(30), 396-429.

Dockett, S., \& Perry, B. (2011). Researching with young children: Seeking assent. Child Indicators Research, 4(2), 231-247.

Dogan-Temur, O., \& Inan, H. (2011). Investigation of the way kindergarten teachers handle time concepts. Egitim Arastirmalari-Eurasian Journal Of Educational Research, 11(43), 217-234.

Dunn, L. M., \& Dunn, L. M. (2007). Peabody picture vocabulary test-Fourth edition manual. Bloomington, MN: Pearson.

Farrant, K., \& Reese, E. (2000). Maternal style and children's participation in reminiscing: Stepping stones in children's autobiographical memory development. Journal of Cognition and Development, 1(2), 193-225.

Fivush, R. (2011). The development of autobiographical memory. Annual Review of Psychology, 62, 559-582.

Fivush, R., Haden, C. A., \& Reese, E. (2006). Elaborating on elaborations: Role of maternal reminiscing style in cognitive and socioemotional development. Child Development, 77(6), 1568-1588. 
Frampton, K. L., Perlman, M., \& Jenkins, J. M. (2009). Caregivers' use of metacognitive language in child care centers: Prevalence and predictors. Early Childhood Research Quarterly, 24(3), 248-262.

Friedman, W. J. (2004). The development of a differentiated sense of the past and the future. Advances in Child Development and Behavior, 31, 229-269.

Gathercole, S. E. (1998). The development of memory. Journal of Child Psychology and Psychiatry, 39(1), 3-27.

Goodvin, R., \& Rolfson, J. (2014). Mothers' attributions in reminiscing conversations about children's successes and failures: Connections with children's selfevaluations. Merrill-Palmer Quarterly, 60(1), 24-52.

Hartup, W.W. (1996). Cooperation, close relationships and cognitive development. In W.M. Bukowski, A.F. Newcomb \& W.W. Hartup (Eds.), The company they keep: Friendship in chilhood and adolescence (pp. 213-237). Cambridge, UK: Cambridge University Press.

Melie, S., William, G., Susanto, S., \& Nanda, D. S. (2020). Foreign language training for visually impaired students in South East Asian countries. https://doi.org/10.31219/osf.io/vjrng.

Nanda, D. S. (2016, May). Fostering the Use of Drama for English Language Learners in the Efl Classroom. In International Conference on Education and Language (ICEL) (p. 7).

Papafragou, A. \& Tantalou, N. (2004). Children's computation of implicatures. Language Acquisition, 12, 71-82. 
Psaltis, C. \& Duveen, G. (2007). Conservation and conversation types: Forms of recognition and cognitive development. British Journal of Developmental Psychology, 25, 79-102.

Siegal, M. \& Surian, L. (2007). Conversational understanding in young children. In E. Hoff \& M. Shatz (Eds.), Handbook of language development (pp. 304-323). New York: Blackwell.

Susanto, S. (2015). A Systemic Functional Study on the Conversational Structure of an Indonesian Spontaneous Dialogue. English Review: Journal of English Education, 4(1), 122-129.

Susanto, S. (2016). A case study of prosodic phrasal grouping and intonational prominence in language acquisition. English Review: Journal of English Education, 4(2), 289-295.

Trognon, A. (2002). Speech acts and the logic of mutual understanding. In D. vanderveken \& S. Kubo (Eds.), Essays in speech acts theory (pp. 121-133). Amsterdam: John Benjamins Publishing Company.

Trognon, A. \& Batt, M. (2010). Interlocutory logic: a unified framework for studying conversational interaction. In J. Streeck (Ed.), New adventures in language and interaction (pp. 9-46). Amsterdam: John Benjamins Publishing Company. 